\title{
Primary pulmonary cavitating carcinomas
}

\author{
M. RA Y CHA U D H U R I \\ Institute of Pathology, Medical Faculty of Rotterdam, The Netherlands
}

A primary lung cancer can produce a cavity in three ways. The first is 'cavitary necrosis' due to breakdown of the growth itself. The second is 'stenotic abscess' due to infection and breakdown of the lung parenchyma distal to bronchial obstruction caused by the growth. The third type is 'spill-over abscess'.

In the present series, necrosis and cavitation were observed in 100 cases out of a total of 632 primary bronchial carcinomas seen at the London Chest Hospital from July 1967 to June 1970. There were 91 males and nine females with an average age of 58.45 years. All except one smoked very heavily and had considerable symptoms. The size of the cavities ranged from 1 to $10 \mathrm{~cm}$ and their wall thickness from 0.5 to $3 \mathrm{~cm}$. They were single in 92 cases and multiple (up to four) in eight. In 42 cases, the cancerous cavitation was central, in 38 intermediate, and in 20 peripheral. The segments most frequently affected were the apicoposterior segment of the left upper lobe and the superior segment of the left lower lobe. For descriptive purposes, these cavitating carcinomas were also divided into six broad groups on the basis of radiological and pathological correlations. Neoplastic cells in the sputum were found in 64 cases. Bronchoscopy revealed growth in 42 cases and biopsy was positive in 48 . The main microscopic feature was vascular invasion of medium-sized muscular arteries and veins found in the vicinity of every cavitating bronchial carcinoma. Invasion along with tumour plugging of the vessels was observed in 75 cases and thrombosis alone in 55 cases. There were 82 squamous-cell carcinomas, 11 undifferentiated carcinomas of large polygonal-cell type, and seven adeno-alveolar cell carcinomas.

The single most important and noteworthy feature in the present series was that oat-cell carcinoma hardly ever undergoes necrosis. Out of a total of 95 cases observed, only three showed necrosis, and this was minimal and characteristically devoid of cavitation. In oat-cell carcinoma vascular invasion and tumour plugging was not observed, though all showed rapid growth and most of them blocked the lobar bronchi completely. In the light of the present study, the main factors responsible for tumour necrosis were found to be gradual bronchial obstruction and associated vascular involvement, though in many cases an inherent propensity of the tumour played a major role.

A cavity or an abscess in the lung is defined as an abnormal hollow space within the lung parenchyma. Cavitation is one of the commonest phenomena in the lung. The development of the surrounding zone of reaction largely determines the character of the residual structural defect or 'cavity'. Lung abscess in its classical infective form is becoming less and less common, and the proportion of abscesses due to bronchial obstruction has steadily increased with the rising incidence of bronchial carcinoma.

Ameuille (1923) first observed the association of lung abscess and bronchial carcinoma. Describing a patient whose clinical and radiological features were compatible with an ordinary lung abscess, he examined the pus under the microscope and found cancer cells. Since then, Fried (1931), Fishberg and Rubin (1929), Roubier
(1929), Maxwell (1934), Reisner (1936), Hausep and Wolpaw (1940), Gray, Fryfogle, and Goo@. (1951), Brock (1952), Strang and Simpson (1953N Bernhard, Malcolm, and Wylie (1962), Zorini (1967), Berger and Thompson (1967), and man\& others have described necrosis and cavitation if association with bronchial carcinoma. According to these authors the incidence ranges from les? than $2 \%$ to more than $25 \%$. This wide discre pancy lies in the fact that most of these clinicoradiological studies failed to reveal a cavity in ${ }^{0}$ homogeneous opacity, because a combined clinicopathological study was not made in correla을 tion with the necropsy (Rosedale and Mackays 1936 ; Strang, 1949). Thus, in many instances, alO though the tumour was necrotic, the degenerated material remained in situ without being coughed up, and although the tumour is from the patholo 
gist's standpoint a cavitating carcinoma, the radiographic appearance is not one of cavitation. The aim of the present study is to investigate the causes of necrosis and eventual cavitation in bronchial carcinoma.

\section{METHOD AND MATERIALS}

One hundred examples of cavitating bronchial carcinoma were observed in a combined radiological and histological survey covering the years July 1967 to June 1970 at the London Chest Hospital. They were obtained from a thorough examination of lungs or lobes from 632 patients with primary bronchial carcinoma; 413 were surgical specimens and 219 were taken at necropsy.

Before any anatomical study of the lung is undertaken, the lung must be inflated and re-expanded to life size. As the available methods of inflation and fixation were found to be unsatisfactory for the present study, an alternative technique was devised. Its aims were (1) to re-inflate the lung to its original dimensions so as to enable radiographs to be taken, and (2) to fix the lung rapidly in the fully expanded state for accurate histological study.

The first aim was achieved simply by inflating the lung with air impregnated with formaldehyde pumped into the bronchus under low pressure (40 to $60 \mathrm{mmHg}$ ). Radiographs of the inflated lung, together with bronchograms and angiograms where necessary, were taken and developed and as soon as they had been checked and passed as satisfactory, the lung was disconnected from the air pump. The second aim was fulfilled by running $10 \%$ aqueous formol saline at a pressure of $120 \mathrm{~cm}$ of water through a cannula tied into the bronchus until the whole lung was filled with liquid formalin.

The site, size, and shape of the cavitating tumour were then recorded and its relationship to the bronchus and pleura was noted along with any other associated abnormalities. Sections were taken from the growth with particular attention to (a) the histological type of the tumour, $(b)$ invasion of vessels (lymphatics/veins/arteries), (c) thrombosis of vessels (veins/arteries), and (d) blocking of bronchi (major/ segmental/terminal).

Slides were stained routinely with haematoxylin and eosin and, where necessary, Verhoeff/van Gieson stain was used. Whole-lung preparations of a few specimens were also made to study further the macroscopic appearances of the necrotic and cavitating carcinomas and associated changes. The purpose was to provide a permanent record. All cavitating primary bronchial carcinomas were screened for neoplastic cells in both the sputum and bronchial washings (trap specimens) on at least five occasions, and wherever they were associated with pleural effusion examination of the pleural fluid was also made.

There were 91 males and nine females (ratio $10 \cdot 1: 1)$. The age range was 31 to 75 years. The highest incidence of cavitation occurred in the 51-70 years group; the average age was 58.45 years (Table I). Ninety-nine had smoked an average of 30 cigarettes per day for over 30 years. Only one, a female, was a non-smoker. In comparison, $75.06 \%$ of patients with non-necrotic bronchial carcinoma had smoked an average of 10 cigarettes or less per day for 20 years; and $95.93 \%$ of patients with necrotic carcinoma had smoked an average of 20 cigarettes or less per day for 30 years (Table II).

T A B L E I

DISTRIBUTION OF BRONCHIAL CARCINOMA BY AGE AND SEX (CAVITATING)

\begin{tabular}{c|cc|c}
\hline Age & Males & Females & Total \\
\hline $31-40$ & 2 & 1 & 3 \\
$41-45$ & 2 & Nil & 2 \\
$46-50$ & 3 & 2 & 5 \\
$51-55$ & 17 & 1 & 18 \\
$56-60$ & 17 & 1 & 18 \\
$61-65$ & 27 & Nil & 27 \\
$66-70$ & 13 & 2 & 15 \\
$71+$ & 10 & 2 & 12 \\
\hline Total & 91 & 9 & 100 \\
\hline
\end{tabular}

T A B L E II

DISTRIBUTION OF CASES BY DAILY CIGARETTE CONSUMPTION

(A) NON-NECROTIC, NON-CAVITATING GROUP

\begin{tabular}{|c|c|c|c|c|c|c|c|c|}
\hline \multirow{2}{*}{$\begin{array}{c}\text { Age } \\
\text { Group }\end{array}$} & \multirow{2}{*}{$\begin{array}{c}\text { Non- } \\
\text { smokers }\end{array}$} & \multicolumn{6}{|c|}{ Daily Cigarette Consumption } & \multirow{2}{*}{ Total } \\
\hline & & $1-5$ & 6-10 & $11-20$ & $21-30$ & $31-40$ & $\begin{array}{c}\text { Above } \\
40\end{array}$ & \\
\hline $\begin{array}{l}31-40 \\
41-45 \\
46-50 \\
51-55 \\
56-60 \\
61-65 \\
66-70 \\
71+\end{array}$ & $\begin{array}{l}3 \\
5 \\
8 \\
0 \\
1 \\
1 \\
0 \\
0\end{array}$ & $\begin{array}{l}\mathbf{0} \\
0 \\
0 \\
0 \\
0 \\
0 \\
0 \\
0 \\
0\end{array}$ & $\begin{array}{l}0 \\
0 \\
0 \\
0 \\
0 \\
0 \\
8 \\
0\end{array}$ & $\begin{array}{r}0 \\
3 \\
8 \\
5 \\
11 \\
13 \\
16 \\
14\end{array}$ & $\begin{array}{r}10 \\
8 \\
6 \\
15 \\
16 \\
45 \\
19 \\
2\end{array}$ & $\begin{array}{r}2 \\
5 \\
10 \\
18 \\
22 \\
53 \\
10 \\
2\end{array}$ & $\begin{array}{r}0 \\
1 \\
7 \\
9 \\
10 \\
17 \\
2 \\
0\end{array}$ & $\begin{array}{r}15 \\
22 \\
39 \\
47 \\
60 \\
129 \\
55 \\
18\end{array}$ \\
\hline Total & 18 & $\mathbf{0}$ & 8 & 70 & 121 & 122 & 46 & 385 \\
\hline
\end{tabular}

(B) NECROTIC, NON-CAVITATING GROUP

\begin{tabular}{l|r|r|r|r|r|r|r|r}
\hline $31-40$ & 2 & 0 & 0 & 1 & 3 & 2 & 0 & 8 \\
$41-45$ & 3 & 0 & 0 & 0 & 2 & 5 & 0 & 10 \\
$46-50$ & 1 & 0 & 0 & 0 & 1 & 6 & 0 & 8 \\
$51-55$ & 0 & 0 & 0 & 6 & 11 & 7 & 2 & 26 \\
$56-60$ & 0 & 0 & 0 & 5 & 26 & 9 & 4 & 44 \\
$61-65$ & 0 & 0 & 0 & 6 & 12 & 15 & 2 & 35 \\
$66-70$ & 0 & 0 & 0 & 2 & 5 & 3 & 1 & 11 \\
$71+$ & 0 & 0 & 0 & 0 & 1 & 2 & 2 & 5 \\
\hline Total & 6 & 0 & 0 & 20 & 61 & 49 & 11 & 147 \\
\hline
\end{tabular}

(C) CAVITATING GROUP

\begin{tabular}{l|l|l|l|l|l|l|l|l}
\hline $31-40$ & 1 & 0 & 0 & 0 & 0 & 1 & 1 & 3 \\
$41-45$ & 0 & 0 & 0 & 0 & 0 & 0 & 2 & 2 \\
$46-50$ & 0 & 0 & 0 & 0 & 2 & 3 & 0 & 5 \\
$51-55$ & 0 & 0 & 0 & 0 & 5 & 5 & 8 & 18 \\
$56-60$ & 0 & 0 & 0 & 2 & 3 & 8 & 5 & 18 \\
$61-65$ & 0 & 0 & 0 & 3 & 6 & 9 & 9 & 27 \\
$66-70$ & 0 & 0 & 0 & 4 & 4 & 3 & 4 & 15 \\
$71+$ & 0 & 0 & 0 & 0 & 2 & 3 & 7 & 12 \\
\hline Total & 1 & 0 & 0 & 9 & 22 & 32 & 36 & 100 \\
\hline Grand & 25 & 0 & 8 & 99 & 204 & 183 & 93 & 632 \\
\hline
\end{tabular}


Whatever the site, cavitating bronchial carcinomas are always associated with severe symptoms and signs, reflecting the tendencies of these tumours to involve more frequently the larger bronchi, lung parenchyma, and pleura, thereby causing bronchial obstruction, purulent bronchitis, bronchiectasis and also obstructive emphysema, fibrosis, and scarring. In the present study, eight of these patients had no symptoms, 41 had mild symptoms such as winter bro chitis and occasional haemoptysis, while the remai ing 51 had severe symptoms (Table III). Though patients with necrotic or non-necrotic bronchial ca?cinoma had comparatively milder symptoms, no siönificant conclusions could be drawn.

T A B L E I I I

FREQUENCY DISTRIBUTION OF BRONCHIAL CARCINOMA ACCORDING TO SYMPTOMS

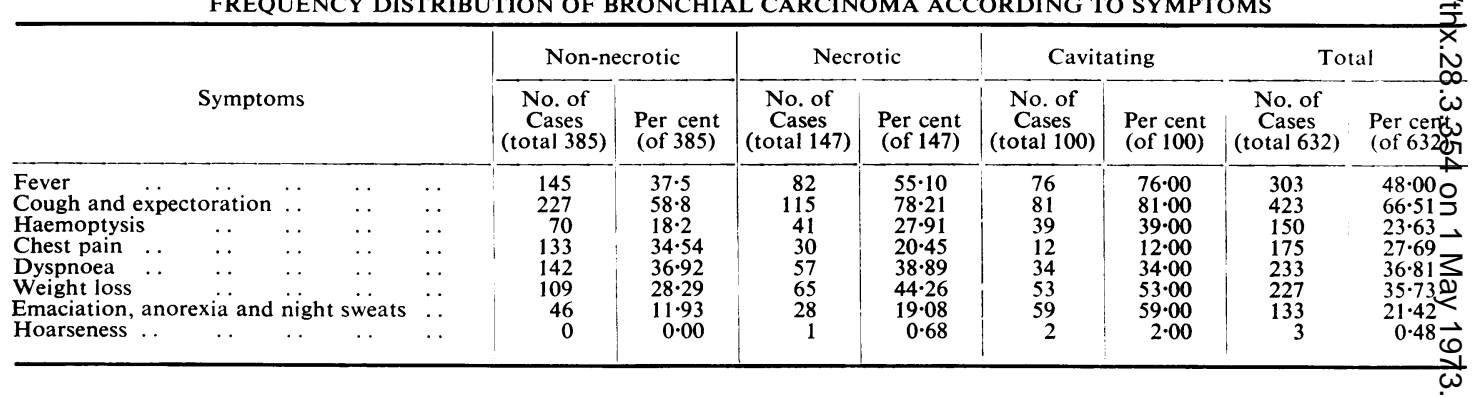

\section{T A B LE IV}

DISTRIBUTION OF BRONCHIAL CARCINOMA BY BRONCHOPULMONARY SEGMENTS

\begin{tabular}{|c|c|c|c|c|c|c|c|c|}
\hline \multirow{2}{*}{ Site } & \multicolumn{2}{|c|}{$\begin{array}{l}\text { Non-necrotic } \\
\text { Non-cavitating }\end{array}$} & \multicolumn{2}{|c|}{$\begin{array}{c}\text { Necrotic } \\
\text { Non-cavitating }\end{array}$} & \multicolumn{2}{|c|}{ Cavitating } & \multicolumn{2}{|c|}{ Total } \\
\hline & $\begin{array}{l}\text { No. of } \\
\text { Cases }\end{array}$ & Per cent* & $\begin{array}{l}\text { No. of } \\
\text { Cases }\end{array}$ & Per cent* & $\begin{array}{l}\text { No. of } \\
\text { Cases }\end{array}$ & Per cent* & $\begin{array}{l}\text { No. of } \\
\text { Cases }\end{array}$ & Per cent产 \\
\hline $\begin{array}{l}\text { Right lung } \\
\text { (a) Upper lobe }\end{array}$ & 181 & $28 \cdot 63$ & 73 & $11 \cdot 55$ & 45 & $7 \cdot 12$ & 299 & $47 \cdot 30=$ \\
\hline $\begin{array}{l}\text { Apical segment } \\
\text { Anterior segment } \\
\text { Posterior segment }\end{array}$ & $\begin{array}{l}39 \\
14 \\
17 \\
\end{array}$ & $\begin{array}{l}6 \cdot 17 \\
2 \cdot 21 \\
2 \cdot 85 \\
\end{array}$ & $\begin{array}{l}23 \\
10 \\
16 \\
\end{array}$ & $\begin{array}{l}3 \cdot 63 \\
1 \cdot 59 \\
2 \cdot 37 \\
\end{array}$ & $\begin{array}{r}13 \\
4 \\
7 \\
\end{array}$ & $\begin{array}{l}2 \cdot 07 \\
0.63 \\
1 \cdot 11\end{array}$ & $\begin{array}{l}75 \\
28 \\
40\end{array}$ & 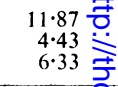 \\
\hline Total & 70 & $11 \cdot 23$ & 49 & $7 \cdot 59$ & 24 & $3 \cdot 81$ & 143 & $22 \cdot 63$ 음 \\
\hline $\begin{array}{l}\text { (b) Middle lobe } \\
\text { Medial segment } \\
\text { Lateral segment }\end{array}$ & $\begin{array}{l}8 \\
0\end{array}$ & $\begin{array}{l}1 \cdot 26 \\
0 \cdot 00\end{array}$ & $\begin{array}{l}0 \\
2\end{array}$ & $\begin{array}{l}0 \cdot 00 \\
0 \cdot 31\end{array}$ & $\begin{array}{l}5 \\
0\end{array}$ & $\begin{array}{l}0 \cdot 79 \\
0 \cdot 00\end{array}$ & $\begin{array}{r}13 \\
2\end{array}$ & 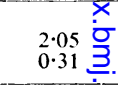 \\
\hline Total & 8 & $1 \cdot 26$ & 2 & 0.31 & 5 & 0.79 & 15 & $2 \cdot 36$ 으 \\
\hline $\begin{array}{l}\text { (c) Lower lobe } \\
\text { Superior segment } \\
\text { Anterior basal segment } \\
\text { Posterior basal segment } \\
\text { Lateral basal segment } \\
\text { Medial basal segment }\end{array}$ & $\begin{array}{r}64 \\
13 \\
21 \\
3 \\
2\end{array}$ & $\begin{array}{r}10 \cdot 14 \\
2 \cdot 06 \\
3 \cdot 32 \\
0 \cdot 47 \\
0 \cdot 31\end{array}$ & $\begin{array}{l}8 \\
5 \\
6 \\
2 \\
1\end{array}$ & $\begin{array}{l}1 \cdot 26 \\
0 \cdot 79 \\
0 \cdot 95 \\
0 \cdot 31 \\
0 \cdot 17\end{array}$ & $\begin{array}{l}8 \\
4 \\
3 \\
1 \\
0\end{array}$ & $\begin{array}{l}1 \cdot 26 \\
0 \cdot 63 \\
0 \cdot 47 \\
0 \cdot 17 \\
0 \cdot 00\end{array}$ & $\begin{array}{r}80 \\
22 \\
30 \\
6 \\
3\end{array}$ & 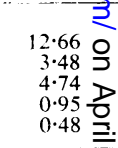 \\
\hline Total & 103 & $16 \cdot 30$ & 22 & $3 \cdot 48$ & 16 & $2 \cdot 53$ & 141 & $22 \cdot 31 \mathrm{~N}$ \\
\hline $\begin{array}{l}\text { Left lung } \\
\text { (a) Upper lobe } \\
\text { Upper division }\end{array}$ & 204 & $32 \cdot 29$ & 74 & $11 \cdot 71$ & 55 & $8 \cdot 70$ & 333 & $52 \cdot 70 \mathrm{~N}$ \\
\hline $\begin{array}{l}\text { Apicoposterior segment } \\
\text { Anterior segment }\end{array}$ & $\begin{array}{l}88 \\
35\end{array}$ & $\begin{array}{r}13 \cdot 91 \\
5 \cdot 53\end{array}$ & $\begin{array}{r}24 \\
8\end{array}$ & $\begin{array}{l}3 \cdot 80 \\
1 \cdot 26\end{array}$ & $\begin{array}{r}24 \\
4\end{array}$ & $\begin{array}{l}3 \cdot 80 \\
0 \cdot 63\end{array}$ & $\begin{array}{r}136 \\
47\end{array}$ & $\begin{array}{r}21.51 \omega \\
7.42 \text { }\end{array}$ \\
\hline Lingular segment (sup. + inf.) & 8 & $1 \cdot 27$ & 6 & $0 \cdot 95$ & 4 & $0 \cdot 63$ & 18 & 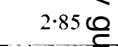 \\
\hline Total & 131 & $20 \cdot 71$ & 38 & $6 \cdot 01$ & 32 & $5 \cdot 06$ & 201 & $31.78 \mathrm{D}$ \\
\hline $\begin{array}{l}\text { (b) Lower lobe } \\
\text { Superior segment } \\
\text { Anterior medial } \\
\text { Basal segment } \\
\text { Posterior basal segment } \\
\text { Lateral basal segment } \\
\text { Medial basal segment }\end{array}$ & $\begin{array}{r}42 \\
7 \\
18 \\
6 \\
0\end{array}$ & $\begin{array}{l}6 \cdot 64 \\
1 \cdot 12 \\
2 \cdot 85 \\
0 \cdot 95 \\
0 \cdot 00\end{array}$ & $\begin{array}{r}22 \\
2 \\
9 \\
3 \\
0\end{array}$ & $\begin{array}{l}3 \cdot 48 \\
0 \cdot 32 \\
1 \cdot 43 \\
0 \cdot 48 \\
0 \cdot 00\end{array}$ & $\begin{array}{r}15 \\
3 \\
3 \\
2 \\
0\end{array}$ & $\begin{array}{l}2 \cdot 37 \\
0 \cdot 48 \\
\\
0 \cdot 48 \\
0 \cdot 32 \\
0 \cdot 00\end{array}$ & $\begin{array}{r}79 \\
12 \\
30 \\
11 \\
0\end{array}$ & 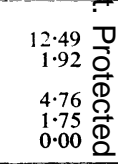 \\
\hline Total & 73 & $11 \cdot 56$ & 36 & $5 \cdot 71$ & 23 & $3 \cdot 65$ & 132 & $20.92 \stackrel{\sigma}{<}$ \\
\hline Grand total & 385 & $60 \cdot 92$ & 147 & $23 \cdot 26$ & 100 & $15 \cdot 82$ & 632 & $100 \cdot 00$ 응 \\
\hline
\end{tabular}


In 42 cases, the cancerous cavitation was central, in 38 intermediate, and in 20 peripheral. Central cavitating bronchial carcinomas are located in the main or lobar bronchi and are nearly always visible on bronchoscopy. Intermediate cavitating carcinomas are located in the segmental bronchi and are visible on bronchoscopy only if they lie at the segmental orifices. Peripheral cavitating bronchial carcinomas are situated at the periphery of the lung, arising in the minute distal bronchi and bronchioles which cannot be seen with the naked eye, and are not ordinarily visible on bronchoscopy. The right lung was involved in 45 cases and the left in 55. The segments most frequently affected were the apicoposterior segment of the left upper lobe ( 24 cases) and the superior segment of the left lower lobe (15 cases), followed by the apical segment of the right upper lobe ( 7 cases), the superior segment of the right lower lobe (8 cases), and the posterior segment of the right upper lobe ( 7 cases) (Table IV).

There were 82 squamous-cell carcinomas, 11 undifferentiated carcinomas of large polygonal-cell type, and seven adeno-alveolar cell carcinomas (Table V).

\section{T A B LE V}

\begin{tabular}{|c|c|}
\hline & $\begin{array}{l}\text { No. of } \\
\text { Cases }\end{array}$ \\
\hline $\begin{array}{l}\text { III Cavitating group: } \\
\text { Squamous-cell carcinoma } \\
\text { (i) Well differentiated keratinising } \\
\text { (ii) Well differentiated non-keratinising } \\
\text { (iii) Moderately well differentiated keratinising } \\
\text { (iv) Moderately well differentiated } \\
\text { non-keratinicing } \\
\text { (v) Poorly differentiated keratinising } \\
\text { (vi) Poorly differentiated non-keratinising }\end{array}$ & $\begin{array}{r}16 \\
0 \\
22 \\
\\
5 \\
23 \\
16\end{array}$ \\
\hline Total & 82 \\
\hline $\begin{array}{l}\text { Undifferentiated large polygonal-cell carcinoma } \\
\text { Oat-cell carcinoma } \\
\text { Adenocarcinoma } \\
\text { (i) Mucus secreting } \\
\text { (ii) Non-mucus secreting }\end{array}$ & $\begin{array}{r}11 \\
0 \\
2 \\
2\end{array}$ \\
\hline Total & 4 \\
\hline Alveolar-cell carcinoma & 3 \\
\hline Grand total & 100 \\
\hline
\end{tabular}

The cavities varied in size, ranging from less than $1.0 \mathrm{~cm}$ to over $10 \mathrm{~cm}$, and had irregular walls varying from 0.5 to $3.0 \mathrm{~cm}$ in thickness. They were single in 92 cases and multiple (up to four) in eight. For the purpose of description, these cavitating carcinomas were divided into six groups. The data for this classification were obtained by scrutinizing the radiographs of the inflated lung or lobe and correlating them with the macroscopic features of the specimen.

(A) CAVITIES WITH THICK IRREGULAR WALLS There were 21 such cavitating carcinomas in the present series. Seventeen were examples of breaking-down peripheral primary bronchial carcinomas. The remaining four represented excavation of the lung paren- chyma distal to an endobronchial growth. On the chest radiograph they simulate typically large infective abscesses. The significant difference is in the walls of malignant cavities which are usually thick and irregular and always exhibit nodulations of the internal contour (mammillations) (Fig. 1). Being peripheral in situation, on bronchoscopy (in 20 patients) the growth was visible in only seven cases, although biopsy revealed cancer in 11 cases and neoplastic cells were found in the sputum in 13. There were 17 squamous-cell carcinomas, the remaining four being undifferentiated carcinomas of large polygonalcell type. Sixteen were surgical and five necropsy specimens. Nine of the 16 surgical patients were followed up for more than three years. Five are dead, and the remaining four are seriously ill. The other seven have been followed up for less than a year and are well.

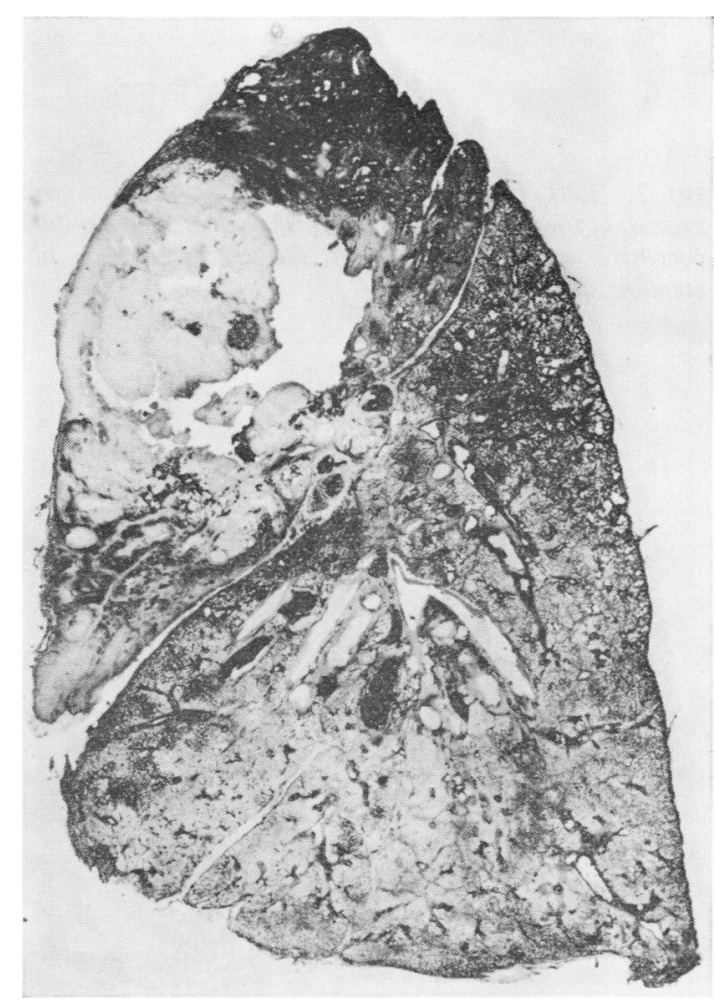

FIG. 1. Whole-lung paper section of a left pneumonectomy specimen exhibiting the characteristic internal mammillations of 'cavitary necrosis'. Normal size $\times 1 / 7$.

(B) ROUND OR OVOID GROWTHS WITH CENTRAL OR ECCENTRIC EXCAVATION Twenty-two carcinomatous abscesses of this type were observed (Fig. 2). They usually represent the early stages of central necrosis in tumours of intermediate location. On bronchoscopy only five revealed growth, though biopsy was posi- 


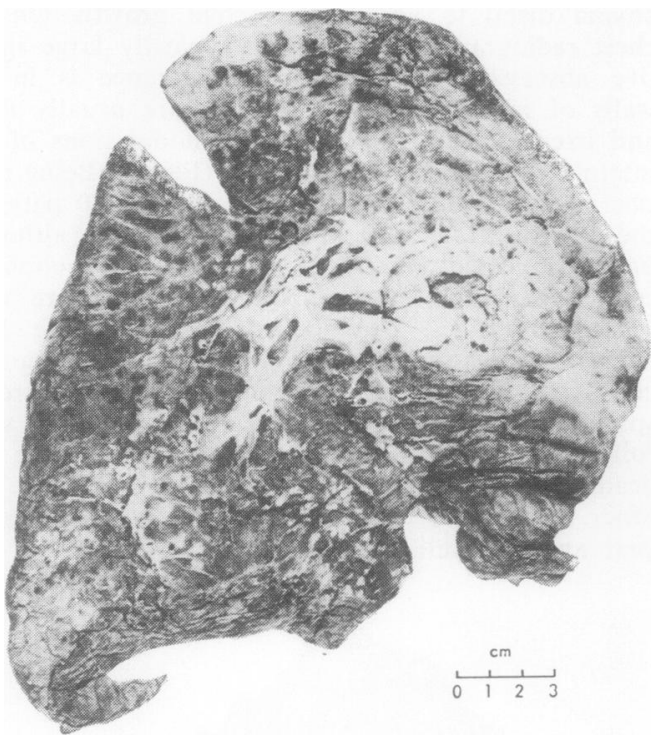

FIG. 2. Left pneumonectomy specimen with an ovoid growth in the anterior segment of the upper lobe exhibiting eccentric excavation, one of the characteristics of a stenotic abscess'. N.S. $\times 1 / 7$.

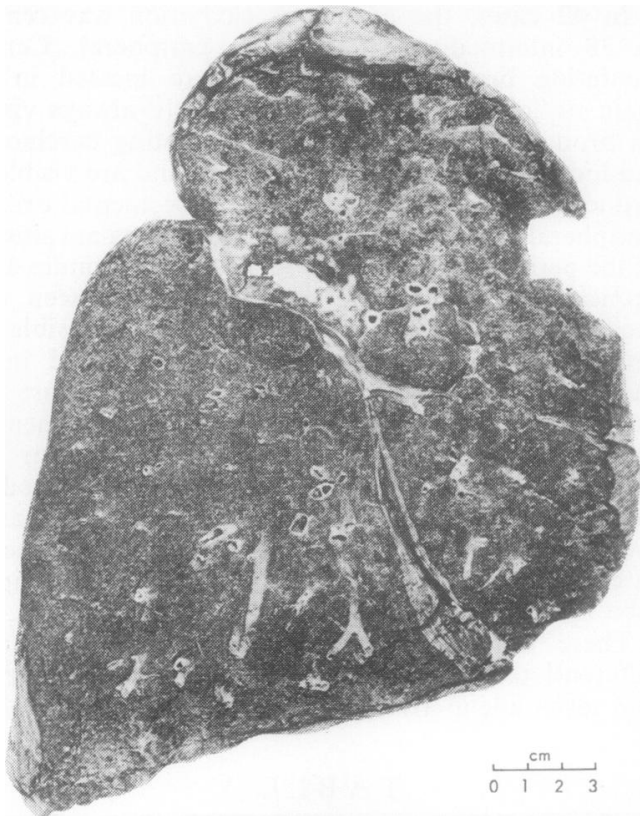

FIG. 3. Left pneumonectomy specimen containing thin walled irregular cavities resembling cysts. N.S. $\times 1 / 7$.

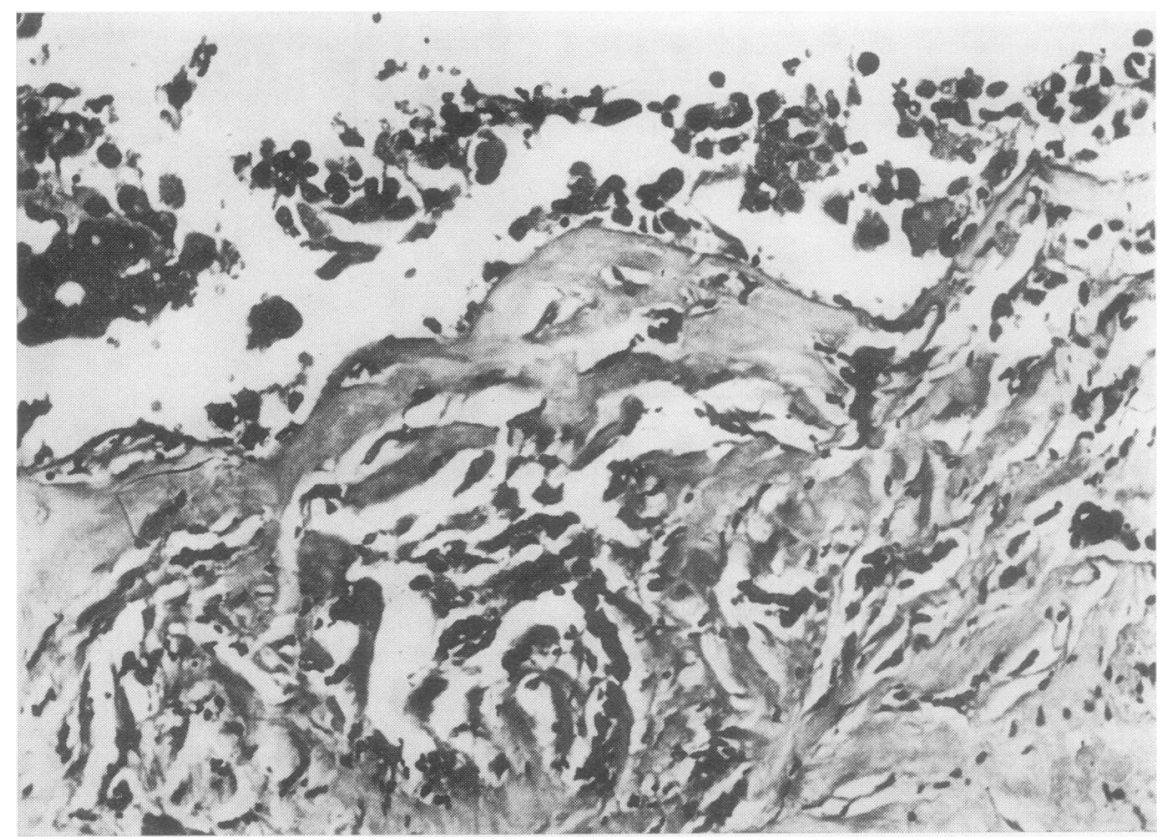

FIG. 4. Cancer cells lining cysts. Haematoxylin and eosin $\times 255$. 


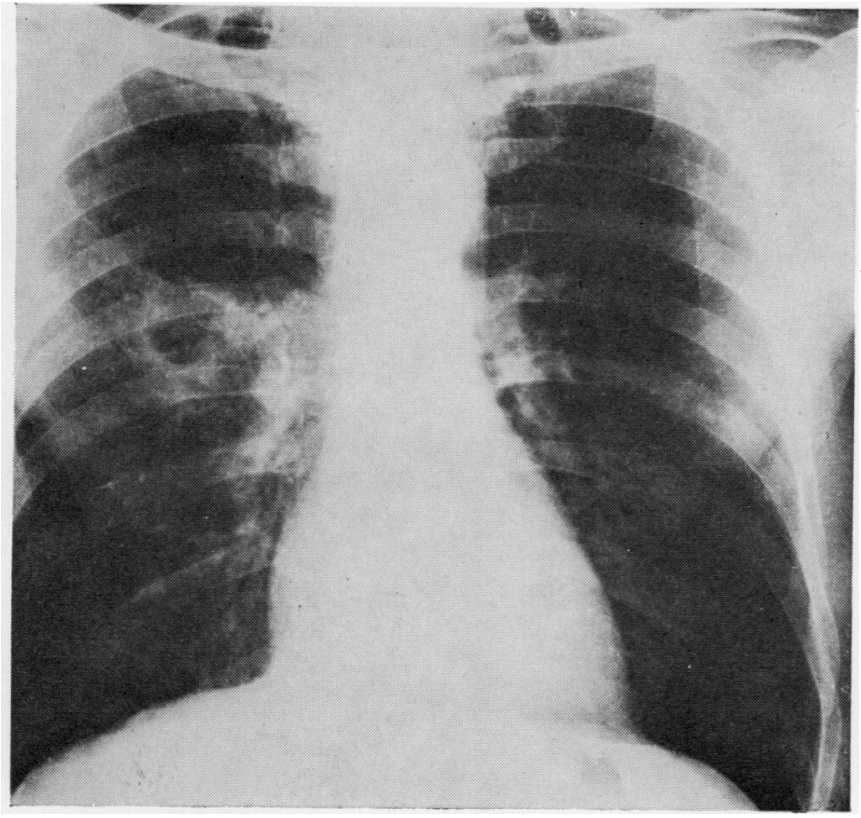

FIG. 5. Chest film showing an intermediately situated cavitating carcinoma with surrounding pneumonitis.

tive in seven and neoplastic cells were present in the sputum in 14 cases. Twenty were squamous-cell carcinomas, one was an undifferentiated carcinoma of large polygonal-cell type, and the other an adenocarcinoma. All were surgical specimens. Eight patients were followed for more than three years; three are dead, two seriously ill, and the remaining three are well and working. The other 14 have been followed up for less than a year and all are well.

(c) SOLID LOBES CONTAINING A CAVITY These are examples of secondary carcinomatous abscesses and they occur in the infected lung parenchyma distal to the growth. Fifteen such abscesses were encountered, of which seven were associated with collapse and consolidation. On bronchoscopy a view of the growth was obtained in 11 cases and a positive biopsy in nine. In 11, neoplastic cells were found in the sputum. There were 12 squamous-cell carcinomas, two adenocarcinomas, and one undifferentiated carcinoma of large polygonal-cell type. All were surgical specimens, the patients being followed up for more than three years. Four are dead, two are critically ill, and the remaining nine are well.

(D) THIN-WALled CAVITIES RESEMBLING CYSTS These are rare and arise in pre-existing air cysts (due to obstructive emphysema) which become lined by cancer cells (Figs. 3 and 4). Only three were encountered. As was expected, bronchoscopy was normal and biopsy negative. They were diagnosed only because

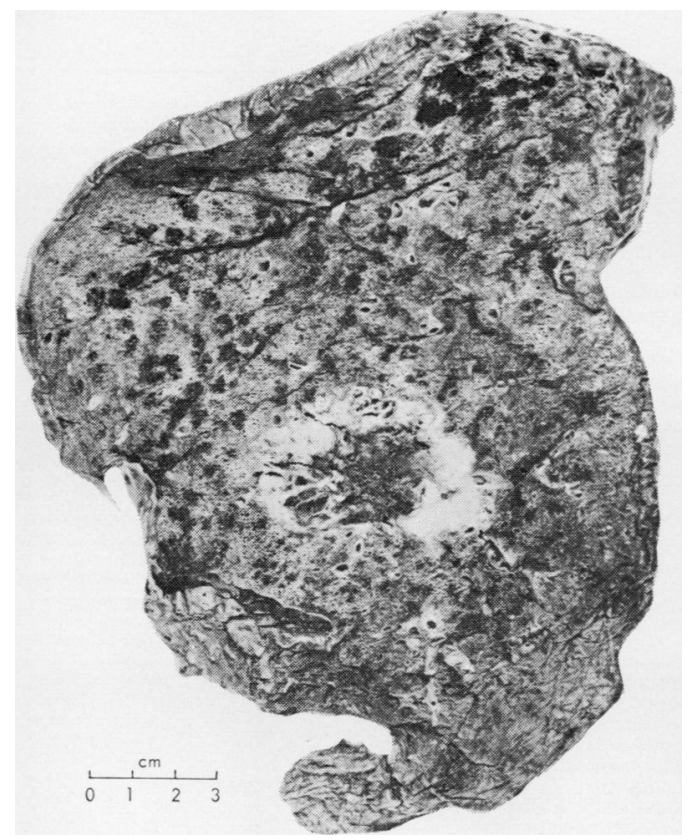

FIG. 6. Right upper lobe exhibiting the characteristic rings of pneumonitis. N.S. $\times 1 / 7$. 
of the repeated presence of cancer cells in the sputum. There was one example each of squamous-cell carcinoma, undifferentiated carcinoma of large polygonal-cell type, and adenocarcinoma. All were surgical specimens. Follow-up studies for more than three years revealed severe dyspnoea in only one patient; the remaining two are well.

(E) CAVITIES WITH SURROUNDING PNEUMONITIS These carcinomatous abscesses are a variant of (C) with less extensive consolidation. The pneumonitis forms a dense zone resembling a ring on the chest radiograph (Figs. 5 and 6). Four peripheral carcinomas had these features. All were examples of squamouscell carcinoma with neoplastic cells persistently present in the sputum. The patients were followed for more than three years and all are well.

(F) SMALL CAVITIES IN LARGE IRREGULAR GROWTHS These carcinomatous abscesses were often undetected in routine chest radiographs and were revealed only when the lungs or lobes were radiographed after proper inflation and confirmed after fixation and systematic cutting. Most were examples of 'stenotic abscesses' (Fig. 7) though 'cavitary necrosis' may occasionally present in this way. This was the largest subgroup in the present series, accounting for as

FIG. 7. Left pneumonectomy specimen containing small 'stenotic abscesses' in the necrotic tumour present in the superior segment of the lower lobe. N.S. $\times 1 / 7$.

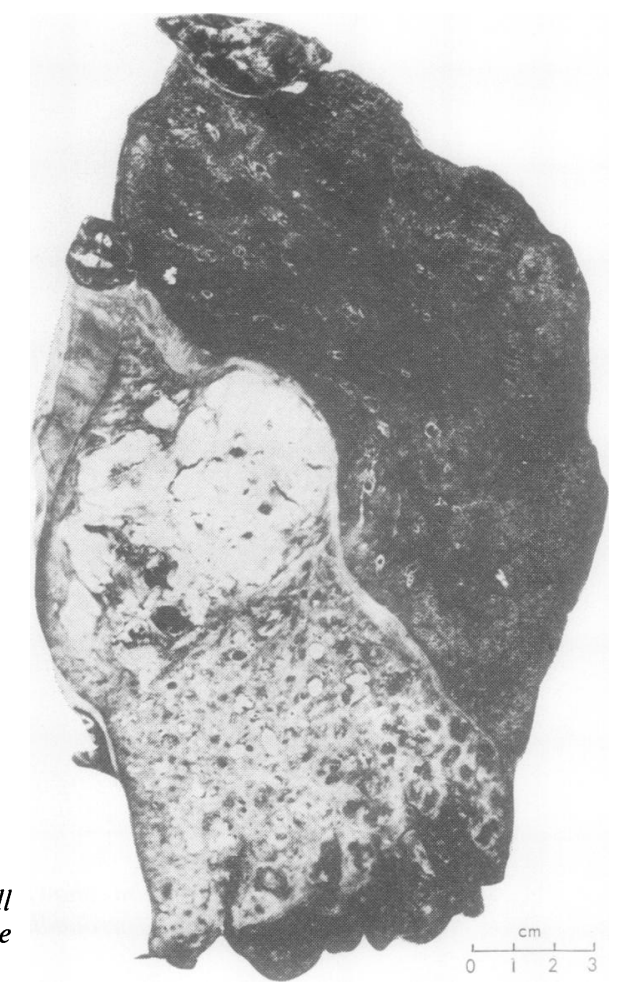

T A B L E V I

DISTRIBUTION OF CAVITATING CARCINOMA BY HISTOLOGICAL TYPE

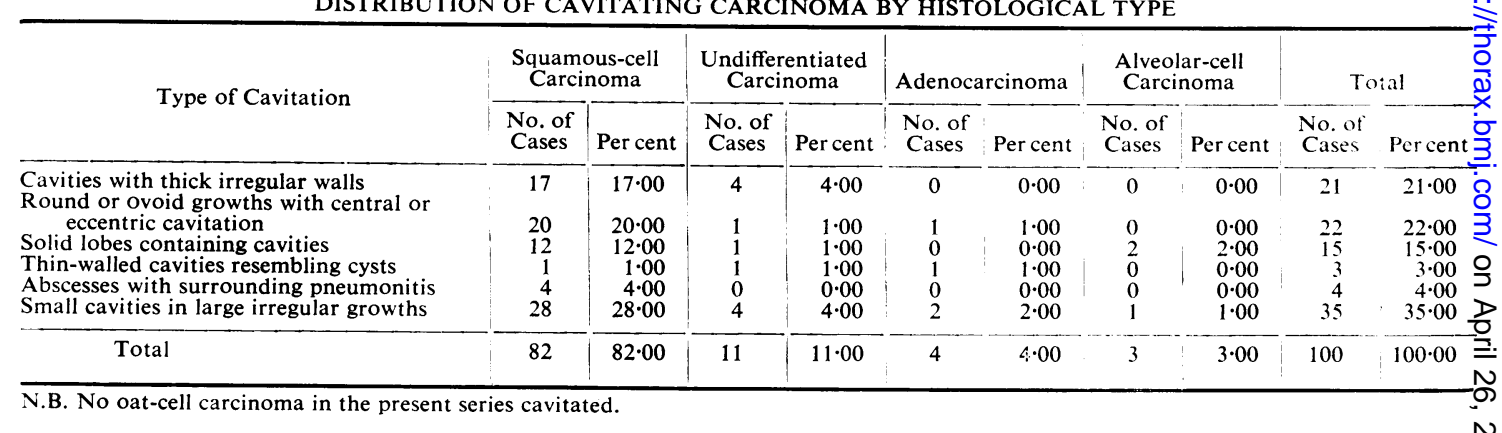

T A B L E V I I

CLINICAL FINDINGS IN CAVITATING CARCINOMA

\begin{tabular}{|c|c|c|c|c|c|c|c|c|c|c|c|}
\hline \multirow{2}{*}{ Type of Cavitation } & \multicolumn{5}{|c|}{ Bronchoscopy } & \multicolumn{2}{|c|}{ Bronchial Biopsy } & \multicolumn{2}{|c|}{ Sputum Cytology } & \multicolumn{2}{|c|}{ Total } \\
\hline & $\begin{array}{l}\text { Not } \\
\text { Done }\end{array}$ & Normal & Stenosis & $\begin{array}{l}\text { Inflam- } \\
\text { mation }\end{array}$ & Growth & Positive & $\begin{array}{l}\text { Nega- } \\
\text { tive }\end{array}$ & Positive & $\begin{array}{l}\text { Nega- } \\
\text { tive }\end{array}$ & $\begin{array}{l}\text { No. of } \\
\text { Cases }\end{array}$ & Per cen \\
\hline $\begin{array}{l}\text { Cavities with thick irregular walls } \\
\text { Round or Ovoid growths with }\end{array}$ & 1 & 6 & 5 & 2 & 7 & 11 & 9 & 13 & 8 & 21 & $21 \cdot 00$ \\
\hline $\begin{array}{l}\text { central or eccentric cavitation } \\
\text { Solid lobes containing cavities } \\
\text { Thin-walled cavities resembling }\end{array}$ & $\begin{array}{l}0 \\
0\end{array}$ & $\begin{array}{l}4 \\
2\end{array}$ & $\begin{array}{l}9 \\
1\end{array}$ & $\begin{array}{l}4 \\
1\end{array}$ & $\begin{array}{r}5 \\
11\end{array}$ & $\begin{array}{l}7 \\
9\end{array}$ & $\begin{array}{r}15 \\
6\end{array}$ & $\begin{array}{l}14 \\
11\end{array}$ & $\begin{array}{l}8 \\
4\end{array}$ & $\begin{array}{l}22 \\
15\end{array}$ & $\begin{array}{l}22 \cdot 00 \\
15 \cdot 00\end{array}$ \\
\hline $\begin{array}{l}\text { cysts } \\
\text { Cavities with surrounding }\end{array}$ & 2 & 1 & 0 & 0 & 0 & - & - & 3 & 0 & 3 & $3 \cdot 00$ \\
\hline $\begin{array}{l}\text { pneumonitis } \\
\text { Small cavities in large irregular }\end{array}$ & 0 & 2 & 1 & 0 & 1 & 1 & 3 & 4 & 0 & 4 & $4 \cdot 00$ \\
\hline growths & 4 & 7 & 4 & 1 & 19 & 21 & 10 & 19 & 16 & 35 & $35 \cdot 00$ \\
\hline Grand total & 7 & 22 & 20 & 18 & 43 & 49 & 43 & 64 & 36 & 100 & $100 \cdot 00$ \\
\hline
\end{tabular}




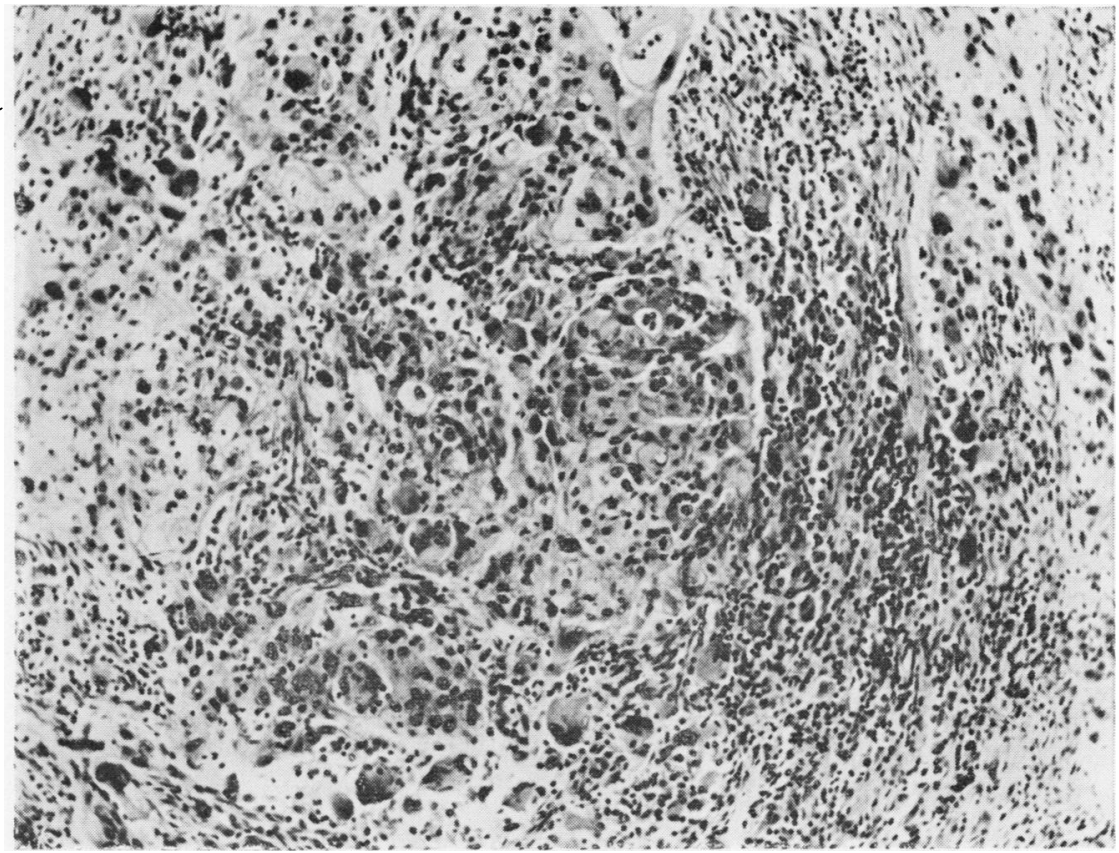

FIG. 8. In the consolidated lobe beyond the obstruction, extensive pneumonitis with a collection of characteristic intra-alveolar cholesterol-laden phagocytes. Haematoxylin and eosin $\times 160$.

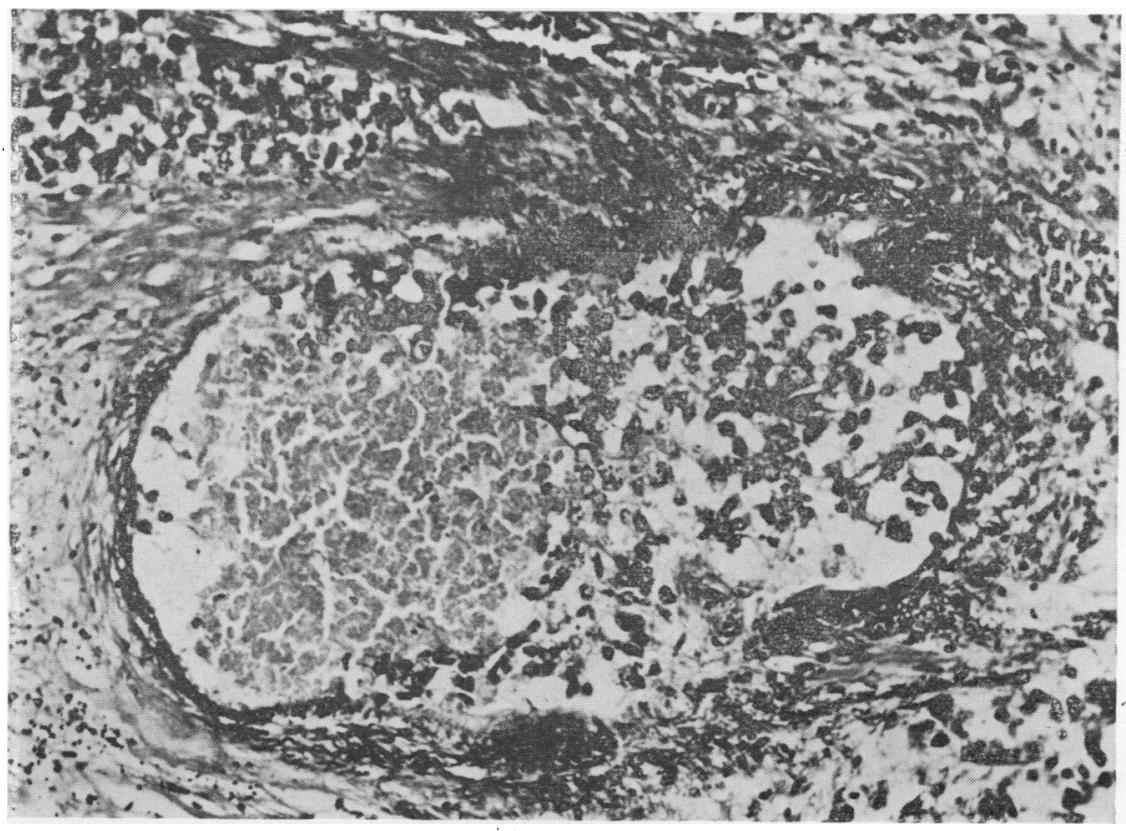

FIG. 9. Vascular invasion of a pulmonary vein. Verhoeff's van Gieson elastic stain. $\times 255$. 


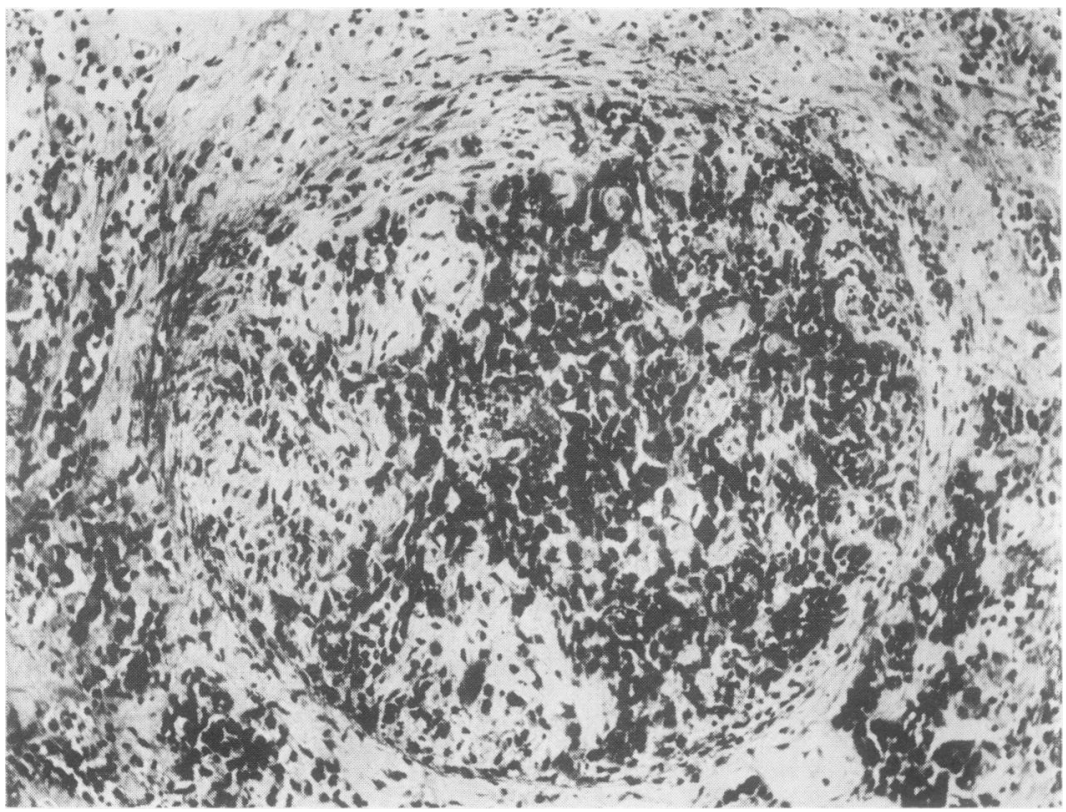

FIG. 10. Tumour plugging of a medium-sized muscular pulmonary artery. Elastic van Gieson. $\times 255$.

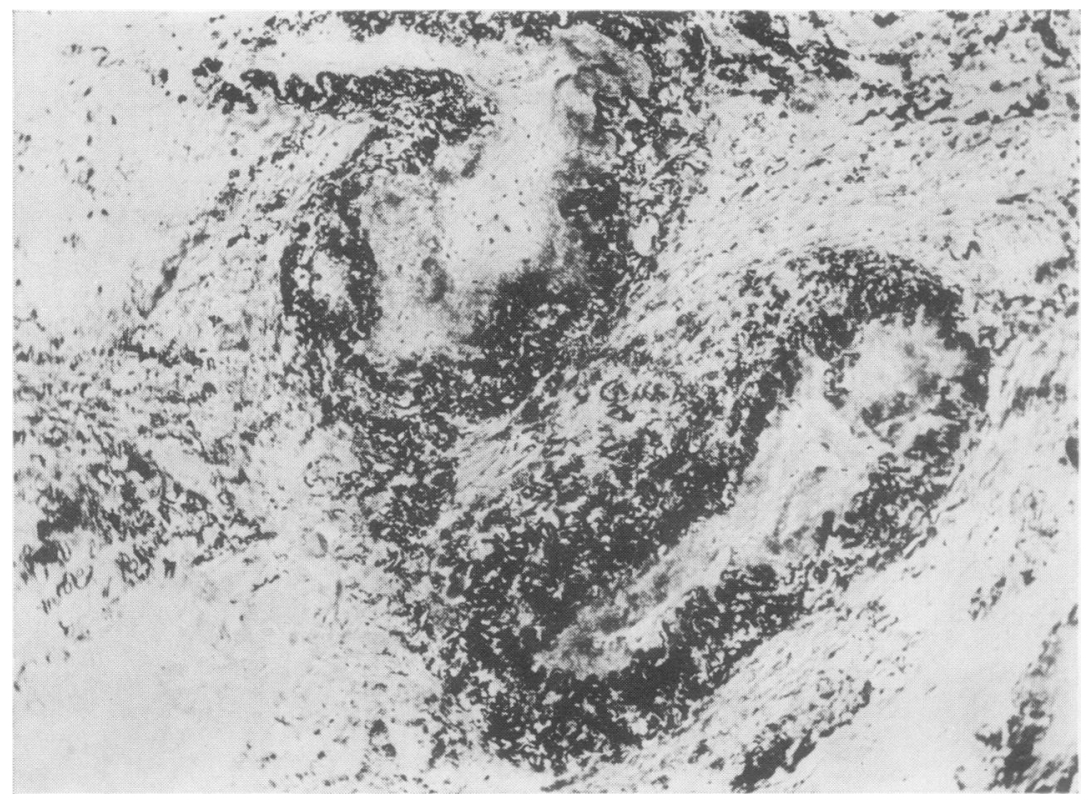

FIG. 11. Bland thrombosis of pulmonary vessels around a cavitating scar carcinoma. Elastic van Gieson. $\times 255$. 
many as 35 of the 100 cases. In 19 of them, bronchoscopy revealed a growth and biopsy was positive in 21 , although sputum contained cancer cells in only 19 cases. There were 28 squamous-cell carcinomas, four undifferentiated carcinomas of large polygonal-cell type, and three adenocarcinomas. Twenty-five were surgical specimens; the other 10 were found at necropsy. A three-year follow-up revealed 17 deaths, four with severe dyspnoea; the remaining four patients are well (Tables VI and VII).

Vascular invasion, i.e., infiltration of cancer cells through the media with growth embedded in the intima, was frequently encountered on microscopical examination of these cavitating carcinomas (Fig. 9). Often mixed with blood, the cancer cells produced socalled tumour thrombus, occasionally causing tumour emboli. However, with tumour plugging (Fig. 10), vascular invasion was invariably found. In a few cases, solitary bland thrombosis occurring from the normal constituents of the blood was observed (Fig. 11). The vessels involved were usually medium-sized muscular arteries and veins in and around the growth. Vascular invasion was present in $100 \%$, invasion with tumour plugging in $75 \%$, and thrombosis of at least one vessel in $55 \%$ of the present cases (for comparison with non-necrotic and necrotic but noncavitating bronchial carcinomas, see Tables VIII and IX).
T A B LE V I II

VASCULAR INVASION IN BRONCHIAL CARCINOMA AT DIFFERENT SITES

\begin{tabular}{|c|c|c|c|c|c|c|}
\hline \multirow{2}{*}{ Site } & \multicolumn{2}{|c|}{$\begin{array}{l}\text { Vessels } \\
\text { Invaded }\end{array}$} & \multicolumn{2}{|c|}{$\begin{array}{l}\text { Vessels not } \\
\text { Invaded }\end{array}$} & \multicolumn{2}{|c|}{ Total } \\
\hline & $\begin{array}{l}\text { No. of } \\
\text { Cases }\end{array}$ & $\begin{array}{c}\text { Per } \\
\text { cent* }\end{array}$ & $\begin{array}{l}\text { No. of } \\
\text { Cases }\end{array}$ & $\underset{\text { cent }}{\text { Per }}$ & $\begin{array}{l}\text { No. of } \\
\text { Cases }\end{array}$ & $\begin{array}{c}\text { Per } \\
\text { cent* }\end{array}$ \\
\hline $\begin{array}{l}\text { Central } \\
\text { Non-necrotic } \\
\text { Necrotic } \\
\text { Cavitating }\end{array}$ & $\begin{array}{c}200 / 200 \\
64 / 64 \\
42 / 42\end{array}$ & $\begin{array}{l}100 \cdot 00 \\
100 \cdot 00 \\
100 \cdot 00\end{array}$ & $\begin{array}{l}0 / 200 \\
0 / 64 \\
0 / 42\end{array}$ & $\begin{array}{l}0.00 \\
0.00 \\
0.00\end{array}$ & $\begin{array}{r}200 \\
64 \\
42\end{array}$ & $\begin{array}{l}65 \cdot 33 \\
20 \cdot 96 \\
13 \cdot 71\end{array}$ \\
\hline Total & $306 / 306$ & $100 \cdot 00$ & 0 & 0.00 & 306 & $100 \cdot 00$ \\
\hline $\begin{array}{l}\text { Intermediate } \\
\text { Non-necrotic } \\
\text { Necrotic } \\
\text { Cavitating }\end{array}$ & $\begin{array}{l}79 / 96 \\
41 / 41 \\
38 / 38\end{array}$ & $\begin{array}{r}82 \cdot 24 \\
100 \cdot 00 \\
100 \cdot 00\end{array}$ & $\begin{array}{r}17 / 96 \\
0 / 41 \\
0 / 38\end{array}$ & $\begin{array}{r}17 \cdot 72 \\
0.00 \\
0.00\end{array}$ & $\begin{array}{l}96 \\
41 \\
38\end{array}$ & $\begin{array}{l}54 \cdot 73 \\
23 \cdot 47 \\
21 \cdot 80\end{array}$ \\
\hline Total & $158 / 175$ & $90 \cdot 29$ & $17 / 175$ & $9 \cdot 71$ & 175 & $100 \cdot 00$ \\
\hline $\begin{array}{l}\text { Peripheral } \\
\text { Non-necrotic } \\
\text { Necrotic } \\
\text { Cavitating }\end{array}$ & $\begin{array}{l}36 / 89 \\
42 / 42 \\
20 / 20\end{array}$ & $\begin{array}{r}40 \cdot 48 \\
100 \cdot 00 \\
100 \cdot 00\end{array}$ & $\begin{array}{r}53 / 89 \\
0 / 42 \\
0 / 42\end{array}$ & $\begin{array}{r}59.58 \\
0.00 \\
0.00\end{array}$ & $\begin{array}{l}89 \\
42 \\
20\end{array}$ & $\begin{array}{l}59 \cdot 78 \\
26 \cdot 89 \\
13 \cdot 23\end{array}$ \\
\hline Total & $98 / 151$ & $\widehat{64 \cdot 88}$ & $\overline{53 / 151}$ & $35 \cdot 12$ & 151 & $100 \cdot 00$ \\
\hline Grand total & 562 & 88.92 & $70 / 632$ & $11 \cdot 08$ & 632 & $100 \cdot 00$ \\
\hline
\end{tabular}

N.B. * Percentages refer to the group total and not to the grand tota of 632 except where stated.

T A B LE IX

TUMOUR PLUGGING AND VASCULAR THROMBOSIS IN BRONCHIAL CARCINOMA AT DIFFERENT SITES

\begin{tabular}{|c|c|c|c|c|c|c|c|c|c|c|}
\hline \multirow{2}{*}{ Site } & \multicolumn{2}{|c|}{$\begin{array}{l}\text { Vessels Showing } \\
\text { Tumour Plugging }\end{array}$} & \multicolumn{2}{|c|}{$\begin{array}{l}\text { Vessels not Showing } \\
\text { Tumour Plugging }\end{array}$} & \multicolumn{2}{|c|}{ Vessels Thrombosed } & \multicolumn{2}{|c|}{$\begin{array}{l}\text { Vessels not } \\
\text { Thrombosed }\end{array}$} & \multicolumn{2}{|c|}{$\begin{array}{l}\text { Total No. of Cases } \\
\text { Examined }\end{array}$} \\
\hline & $\begin{array}{l}\text { No. of } \\
\text { Cases }\end{array}$ & Per cent & $\begin{array}{l}\text { No. of } \\
\text { Cases }\end{array}$ & Per cent & $\begin{array}{l}\text { No. of } \\
\text { Cases }\end{array}$ & Per cent & $\begin{array}{l}\text { No. of } \\
\text { Cases }\end{array}$ & Per cent & $\begin{array}{l}\text { No. of } \\
\text { Cases }\end{array}$ & Per cent \\
\hline $\begin{array}{l}\text { Central } \\
\text { Non-necrotic } \\
\text { Necrotic } \\
\text { Cavitating }\end{array}$ & $\begin{array}{l}23 / 200 \\
29 / 64 \\
39 / 42\end{array}$ & $\begin{array}{l}11 \cdot 50 \\
45 \cdot 31 \\
92 \cdot 86\end{array}$ & $\begin{array}{c}177 / 200 \\
35 / 64 \\
3 / 42\end{array}$ & $\begin{array}{r}88 \cdot 50 \\
54 \cdot 69 \\
7 \cdot 14\end{array}$ & $\begin{array}{c}0 / 200 \\
9 / 64 \\
23 / 42\end{array}$ & $\begin{array}{r}0 \cdot 00 \\
14 \cdot 08 \\
54 \cdot 77\end{array}$ & $\begin{array}{c}200 / 200 \\
55 / 64 \\
19 / 42\end{array}$ & $\begin{array}{r}100 \cdot 00 \\
85 \cdot 92 \\
45 \cdot 23\end{array}$ & $\begin{array}{r}200 \\
64 \\
42\end{array}$ & $\begin{array}{l}65 \cdot 33 \\
20 \cdot 96 \\
13 \cdot 71\end{array}$ \\
\hline Total & $91 / 306$ & $29 \cdot 77$ & $215 / 306$ & $70 \cdot 23$ & $32 / 306$ & $10 \cdot 46$ & $274 / 306$ & $89 \cdot 54$ & 306 & $100 \cdot 00$ \\
\hline $\begin{array}{l}\text { Intermediate } \\
\text { Non-necrotic } \\
\text { Necrotic } \\
\text { Cavitating }\end{array}$ & $\begin{array}{l}11 / 96 \\
15 / 41 \\
31 / 38\end{array}$ & $\begin{array}{l}11 \cdot 45 \\
36 \cdot 68 \\
81 \cdot 57\end{array}$ & $\begin{array}{r}85 / 96 \\
26 / 41 \\
7 / 38\end{array}$ & $\begin{array}{l}88 \cdot 55 \\
63 \cdot 32 \\
18 \cdot 43\end{array}$ & $\begin{array}{r}0 / 96 \\
11 / 41 \\
21 / 38\end{array}$ & $\begin{array}{r}0 \cdot 00 \\
26 \cdot 83 \\
55 \cdot 22\end{array}$ & $\begin{array}{l}96 / 96 \\
30 / 41 \\
17 / 38\end{array}$ & $\begin{array}{r}100 \cdot 00 \\
73 \cdot 17 \\
44 \cdot 78\end{array}$ & $\begin{array}{l}96 \\
41 \\
38\end{array}$ & $\begin{array}{l}54 \cdot 73 \\
23 \cdot 47 \\
11 \cdot 80\end{array}$ \\
\hline Total & $57 / 175$ & $32 \cdot 62$ & $118 / 175$ & $67 \cdot 38$ & $32 / 175$ & $18 \cdot 30$ & $143 / 175$ & $81 \cdot 70$ & 175 & $100 \cdot 00$ \\
\hline $\begin{array}{l}\text { Peripherul } \\
\text { Non-necrotic } \\
\text { Necrotic } \\
\text { Cavitating }\end{array}$ & $\begin{array}{l}5 / 89 \\
4 / 42 \\
5 / 20\end{array}$ & $\begin{array}{r}5 \cdot 62 \\
9 \cdot 53 \\
25 \cdot 00\end{array}$ & $\begin{array}{l}84 / 89 \\
38 / 42 \\
15 / 20\end{array}$ & $\begin{array}{l}94 \cdot 38 \\
90 \cdot 47 \\
75 \cdot 00\end{array}$ & $\begin{array}{r}0 / 89 \\
2 / 42 \\
11 / 20\end{array}$ & $\begin{array}{r}0.00 \\
4.76 \\
55.00\end{array}$ & $\begin{array}{r}89 / 89 \\
40 / 42 \\
9 / 20\end{array}$ & $\begin{array}{r}100 \cdot 00 \\
95 \cdot 24 \\
45 \cdot 00\end{array}$ & $\begin{array}{l}89 \\
42 \\
20\end{array}$ & $\begin{array}{l}59 \cdot 78 \\
26 \cdot 89 \\
13 \cdot 33\end{array}$ \\
\hline Total & $14 / 151$ & $9 \cdot 28$ & $137 / 151$ & $90 \cdot 72$ & $13 / 151$ & $8 \cdot 60$ & $138 / 151$ & $91 \cdot 40$ & 151 & $100 \cdot 00$ \\
\hline Grand total & $162 / 632$ & $25 \cdot 63$ & $470 / 632$ & $74 \cdot 37$ & $77 / 632$ & $12 \cdot 21$ & $555 / 632$ & $87 \cdot 79$ & 632 & $100 \cdot 00$ \\
\hline
\end{tabular}

\section{DISCUSS:ON}

One of the modes of presentation of primary bronchial carcinoma is necrosis of the lung parenchyma with eventual cavity or abscess formation. Cavitation in a bronchial carcinoma may arise in three ways. It may be caused by the breakdown of primary growth itself; it may arise in the obstructed and infected portion of the lung distal to a growth causing bronchial obstruction; or it may be caused by bronchial embolism or 'spillover' from an infected primary growth, in which 
case it may be situated in a different lobe from the primary growth, or even in the opposite lung. Cavitation within a growth has been described as primary, and distal to the growth as secondary (Brock, 1952 ; Openshaw, 1952), although these terms are not used universally at present.

The development of necrosis and cavitation in a primary bronchial carcinoma depends to a large extent on the site and histological type of the growth. Koletsky (1938), Gray et al. (1951), Laforet and Laforet (1957), Bernhard et al. (1962), and others indicated that the frequency of cavity formation increases with the histological grade of malignancy and the excavation is more likely to develop in large, widely infiltrating, peripheral carcinomas. In most series, including Davidson (1930), Edwards (1938), Brock (1952), Strang and Simpson (1953), Farber (1954), Hinshaw and Garland (1966), and Spencer (1968), squamous-cell carcinomas and undifferentiated carcinomas of large polygonal-cell type were found to be associated with necrosis and eventual cavitation more often than similarly situated adenocarcimomas.

The primary event in the causation of an infective lung abscess is almost certainly bronchial emboli which carry with them organisms, aerobic and anaerobic (often mixed and symbiotic), and frequently of the types commonly found in the mouth and nasal passages. This embolism sets up an acute segmental or subsegmental pneumonitis, which presumably by causing secondary vascular thrombosis or by direct toxic action upon the lung tissue, gives rise to abscess or even leads to gangrene of the lung (Cutler and Gross, 1936 ; Brock, 1952). However, this phenomenon can explain only cavitation of the 'spill-over' type, and in the present series only six examples of such cavitating bronchial carcinomas were obtained. In all these cases, associated vascular invasion and thrombosis were also noted. As the vascular supply of most bronchial carcinomas is richest at the margins, the cells at the centre of these growing carcinomas die of hypoxia due to lack of oxygen, and the result, as seen by the microscopist, is the familiar picture of necrosis. Yet among the present series, there were oatcell carcinomas of more than $10 \mathrm{~cm}$ in diameter without a trace of necrosis, while some squamouscell carcinomas and undifferentiated carcinomas of large polygonal-cell type, as small as 0.5 to 1.0 $\mathrm{cm}$, presented extensive necrosis in every lesion. These carcinomas, are, therefore, thought to exhibit a tendency to undergo necrosis. In any superficial stratified epithelium, the surface cells dry up and fuse to form a protective keratin layer, if they are exposed to air. With deeper layer multiplication, new cells are constantly pushed towards the surface where in turn they also are converted into keratin to replace the desquamated cells. The same process occurs in the centre of all squamous-cell carcinomas growing slowly but, in the absence of air, the end-product remains semi-liquid in contrast to the horny character of the surface keratin. This is most evident in squamous-cell carcinoma of the mouth, pharynx, and larynx, and, to a lesser extent, of the cervix.

It is improbable that this mechanism of 'cyst' formation can also occur in primary squamouscell carcinoma of the bronchus. In the usual course of events, following occlusion of an arteriole by a viable thrombus of tumour cells, the vessel wall is invaded and access to perivascular spaces is gained. The cancerous process then spreads interstitially or through the alveolar spaces via the pores of Cohn. Eventually the pulmonary architecture is destroyed in the substance of a large tumour and central avascular necrosis ensues. As the tumour breaks into the alveoli, opportunities occur for these semi-liquid contents to communicate with the air passages, and the process of cornification is further facilitated. Continuous respiratory motion also assists in stripping the dehydrated, stratified material from the cavity walls and with continued growth the two combine to increase the size of the cavity while maintaining a wall of relatively constant thickness (Dodd and Boyle, 1961; Berger and Thompson, 1967). These arguments are possible reasons for cavitation in some well-differentiated squamous-cell carcinomas.

Another mechanism postulated to account for cavity formation is 'autophagism', the self-destruction of a tumour by the enzymes it secretes. The enzymes are supposedly lipolytic and proteolytic in type, resulting in digestion of neoplastic as well as surrounding healthy tissue, and they have been observed in pulmonary metastases of pancreatic and colonic adenocarcinomas (Dodd and Boyle, 1961 ; Zorini, 1967). These metastatic carcinomas show a cystic tendency throughout their life, supposedly due to persistence of primitive secretory function. However, the relationship of this cystic tendency to pulmonary cavity formation is not clear. A preliminary search for enzymes in the present seven primary adenocarcinomas revealed no trace of any lipolytic or proteolytic activity, nor in 12 metastatic adenocarcinomas reported previously (Chaudhuri, 1970).

Necrosis can also occur as a consequence of 
treatment with cytotoxic drugs or after irradiation, but none of the patients in this series had received any such treatment.

It seems that the main factors responsible for tumour necrosis are bronchial obstruction and vascular involvement leading to ischaemia. The close proximity of many bronchial carcinomas to large vessels offers tumour tissue ample opportunity for invading both arteries and veins. The frequent occurrence of distant haematogenous metastases after surgical excision is a common experience, and this can occur only when malignant infiltration of the pulmonary veins has taken place. Since Siegert (1893) described macroscopic and microscopic evidence of malignant involvement of the pulmonary veins, Wolf (1895), Weller (1929), Simpson (1929), McDonald and Heather (1939), Aylwin (1951), and Hinson and Nohl (1960) all noted frequent involvement of the pulmonary veins in primary bronchial carcinomas. Galluzi and Payne (1955) and Willis (1966) maintained that though gross invasion of the veins is common, pulmonary arteries, although very frequently surrounded by growth, are rarely found to be invaded at necropsy. However, Pryce and Walter (1960) and the findings in the present study confirm that in primary bronchial carcinomas, invasion of arteries is as frequent as invasion of veins; and the elastic lamina offers no barrier to neoplastic cells. The vessels involved are usually medium-sized muscular arteries and veins. Tumour plugging of the vessels was observed in as many as $75 \% ; 100 \%$ presented frank invasion of veins and arteries. Bland thrombosis alone occurred in $55 \%$ of cases.

The 'stenotic abscess' type of cavity in a primary bronchial carcinoma probably follows a particular sequence of events. When situated either centrally or intermediately, these tumours usually cause incomplete or intermittent bronchostenosis. The process is followed by suppurative obstructive pneumonitis in the part of the lung distal to the growth. Nutrition of the affected segments thus suffers; the blood vessels in the region may show thrombosis and even bland infarcts may be observed (Hanbury, Cureton, and Simon, 1954). The necrosed material is eventually coughed up when communication, however small, is established between the necrotic area and the bronchial tree, and a cavity is formed. In the present series, stenotic cavitation occurred in 17 cases; 14 were central in situation and three intermediate. Eight were squamous-cell carcinomas, six were undifferentiated carcinomas of large polygonal-cell type, and the remaining three were adenocarcinomas.
Secondary carcinomatous abscesses due to 'spill-over' infected tumour emboli from a primary bronchial carcinoma elsewhere in the lung are usually small and localized but may form a diffuse, spreading process ultimately affecting a whole lobe. They may occur in the same lobe as the primary growth but affecting an adjacent segment. When 'spill-over' abscesses occur in the lung opposite to the primary growth, they usually affect one of the classical sites for an inhalation abscess and may give a confusing clinical picture. There were six 'spill-over' abscesses in the present series ; four of them occurred in the superior segment of the left lower lobe and the remaining two in the apical segment of the left upper lobe. Four were histologically squamous-cell carcinomas, the remaining two were adenocarcinomas.

The commonest type of cavitation in a primary bronchial carcinoma is cavitary necrosis. This type usually presents as a large peripheral carcinoma, though in the present series, as many as 28 central carcinomas had broken down to form cavities. The size of the breaking-down portion, and hence the size and character of the resultant cavity, varies considerably. If it is small, only one or two cavities may be seen in the middle of the growth. In other cases, the greater part of the growth may be necrotic, and a large peripheral cavity lined with growth will be found. The wall may be thin (sometimes even cyst-like) or moderately thick ; most significantly, the wall is irregular and shows mammilations. The cavity may be of moderate size relative to the growth and may be placed eccentrically. On microscopic examination the vessels show invasion by cancer cells in all instances, occlusion by tumour plugging in most instances, and bland thrombosis in many cases. Of the 77 pulmonary cancers exhibiting 'cavitary necrosis', 70 were examples of squamouscell carcinoma alone, two were undifferentiated carcinomas of large polygonal-cell type, and the remaining five were adeno-alveolar cell carcinomas.

The single most important feature in this series is that oat-cell carcinoma hardly ever undergoes necrosis. Of the 95 cases, only three showed minimal necrosis, characteristically devoid of cavitation. Vascular invasion and tumour plugging were not observed. All showed rapid growth and most of them blocked the lobar bronchi (as they were almost always central in location) completely.

Cavitation in a primary bronchial carcinoma is correlated with a bad prognosis, because cavitary carcinomas usually show vascular invasion, 
T A B LE $X$

THREE-YEAR SURVIVAL FIGURES FOR RESECTED PRIMARY CAVITATING CARCINOMA

\begin{tabular}{c|c|c|c|c}
\hline Type of Cavitation & $\begin{array}{c}\text { No. of } \\
\text { Cases }\end{array}$ & Dead & $\begin{array}{c}\text { Critically } \\
\text { Ill }\end{array}$ & $\begin{array}{c}\text { Well and } \\
\text { Working }\end{array}$ \\
\hline \begin{tabular}{c|c} 
Cavities with thick \\
irregular walls
\end{tabular} & 9 & 5 & 4 & Nil \\
$\begin{array}{c}\text { Round or ovoid growths } \\
\text { with central or } \\
\text { eccentric excavation }\end{array}$ & 8 & 3 & 2 & 3 \\
$\begin{array}{c}\text { Solid lobes containing } \\
\text { cavities }\end{array}$ & 15 & 4 & 2 & 9 \\
$\begin{array}{c}\text { Thin-walled cavities } \\
\text { resembling cysts }\end{array}$ & 3 & Nil & 1 & 2 \\
$\begin{array}{c}\text { Abscesses with surround- } \\
\text { ing pneumonitis }\end{array}$ & 4 & Nil & Nil & 4 \\
$\begin{array}{c}\text { Small cavities in large } \\
\text { irregular growths }\end{array}$ & 25 & 17 & 4 & 3 \\
\hline Total & 64 & 29 & 13 & 22 \\
\hline
\end{tabular}

and metastases are bound to be more common in them than in non-necrotic, non-cavitating and necrotic, non-cavitating primary bronchial cancers. Table $X$ represents the survival rate of patients with cavitating bronchial carcinomas, three years after pulmonary resection.

In the course of this study, several limitations of morbid anatomy have become apparent. Despite utilization of a wide range of techniquesinflation, radiography, bronchography, angiography, whole-lung paper sections, macroscopic and microscopic examination, and histochemistry -it still remains uncertain why some bronchial carcinomas undergo necrosis and others do not. Ischaemia and bronchial obstruction are undoubtedly major factors but cannot explain every instance of necrosis. It seems unlikely that further studies along purely observational lines will yield much new information.

This paper constitutes part of a Ph.D. thesis accepted by the University of London in 1971. I wish to thank Dr. K. F. W. Hinson, Director in Pathology, Brompton Hospital, London, for allowing me to carry out the work in his department under his constant supervision and guidance.

\section{REFERENCES}

Ameuille, P. (1923). Cancer pulmonaire á forme d'abcès. Bull. Soc. Hôp. Paris, 47, 1315.

Aylwin, J. A. (1951). Avoidable vascular spread in resection for bronchial carcinoma. Thorax, 6, 250.

Berger, M., and Thompson, J. R. (1967). Cavitary carcinomatosis of the lungs. Dis. Chest, 52, 106.

Bernhard, W. F., Malcolm, J. A., and Wylie, R. H. (1962). The carcinomatous abscess; a clinical paradox. New Engl. J. Med., 266, 914.

Brock, R. C. (1952). Lung Abscess, p. 130. Blackwell Scientific Publications, Oxford.

Chaudhuri, M. R. (1970). Cavitary pulmonary metastases. Thorax, 25, 375.

Cutler, E. C., and Gross, R. E. (1936). Nontuberculous abscess of the lung. J. thorac. Surg., 6, 125. Davidson, M. (1930). Cancer of the Lung and Other Intra-
thoracic Tumours, p. 50. Wright, Bristol.

Dodd, G. D., and Boyle, J. J. (1961). Excavating pulmonary metastases. Amer. J. Roentgenol., 85, 277.

Edwards, A. T. (1938). Tumours of the lung. Brit. J. Surg., $\stackrel{\mathbb{\Phi}}{\Omega}$ 26, 166

Farber, S. M. (1954). Lung Cancer, p. 49. Thomas, Spring- के field, Illinois.

Fishberg, M., and Rubin, E. H. (1929). Carcinomatous abscess of the lung. Amer. J. $m$ ?d. Sci., 178, 20.

Fried, B. M. (1931). Primary carcinoma of the lung. Medicine (Baltimore), 10, 373.

Galluzi, S., and Payne, P. M. (1955). Bronchial carcinoma. Brit. J. Cancer, 9, 511.

Gray, H.' K., Fryfogle, J. D., and Good, C. A. (1951). Malignant pulmonary abscesses. Surg. Clin. N. Amer., w 31, 1199.

Hanbury, W. J., Cureton, R. J. R., and Simon, G. (1954). 윽 Pulmonary infarcts associated with bronchogenic carcinoma. Thorax, 9, 304.

Hauser, H. C., and Wolpaw, S. E. (1940). Cavitary bronchogenic carcinoma. Radiology, 34, 698. Hinshaw, H. C., and Garland, L. H. (1966). Diseases of the $\vec{v}$
Chest, Chapters IV \& XX. Saunders, Philadelphia.

Hinson, K. F. W., and Nohl, H. C. (1960). Involvement of the pulmonary veins by bronchogenic carcinoma. Brit. J. Dis. Chest, 54, 54.

Koletsky, S. (1938). Primary carcinoma of the lung. Arch. intern. Med., 62, 636.

Laforet, E. G., and Laforet, M. T. (1957). Non-tuber- $\frac{\mathrm{D}}{\mathrm{D}}$ culous cavitary disease of the lungs. Dis. Chest, 31, 665.

Maxwell, J. (1934). Lung abscess. Quart. J. Med., 3, 467. $\overline{\overline{0}}$

McDonald, S., Jr., and Heather, J. C. (1939). Neoplastic 3 invasion of the pulmonary veins and left auricle. J. Path. Bact., 48, 533.

Openshaw, C. R. (1952). Cavitary malignancy of the lungs. Ph.D. thesis, University of Minnesota.

Pryce, D. M., and Walter, J. B. (1960). The frequency of gross vascular invasion in lung cancer with special $\underset{.}{ }$ reference to arterial invasion. J. Path. Bact., 79, 141.

Reisner, D. (1936). Carcinomatous cavities of the lungs. Quart. Bull. Sea View Hosp., 1, 322.

Rosedale, R. S., and Mackay, D. R. (1936). A study of $57 \gtreqless$ cases of bronchogenic carcinoma. Amer. J. Cancer, 26, 0 493.

Roubier, C. (1929). Cavitary carcinoma. J. Méd. Lyon, 10, 615.

Siegert, F. (1893). On the histogenesis of primary lung
cancer. Virchows Arch. path. Anat., 134, 287.

Simpson, S. L. (1929). Primary carcinoma of the lung. N Quart. J. Med., 22, 413.

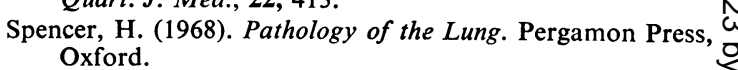

Strang, C. (1949). Bronchial carcinoma. M.D. thesis, University of Durham.

, and Simpson, J. A. (1953). Carcinomatous abscess of $\stackrel{\mathscr{C}}{+}$ the lung. Thorax, 8, 11 .

Weller, C. V. (1929). The pathology of primary carcinoma of the lung. Arch. Path., 7, 478.

Willis, R. A. (1966). Pathology of Tumours. Butterworth, London.

Wolf, K. (1895). Der primäre Lungenkrebs. Fortschr. Med., ర్ 13,725 .

Zorini, A. O. (1967). Primary carcinomatous cavities of the lung. Dis. Chest, 52, 329. 